\title{
Reply to 'Comment on The geometry and stratigraphic position of the Maassluis Formation (western Netherlands and south-eastern North Sea)'
}

\section{H.S.M. Jansen}

J\&G, J. Rosenkrantzlaan 35, 2104 CC Heemstede. Email: strats@xs4all.nl

Manuscript received: March 2005; accepted: March 2005

In their comment, Wesselingh et al. say that pronounced glacioeustacy renders the detailed discussions about age intervals obsolete and that they fail to see the application of the Haq curves for age estimates in the Maassluis Formation can make much sense. We would argue the following:

- Eustacy and sediment supply are the driving forces behind sequence formation and configuration. As our model shows, the overall picture of the Pliocene/Pleistocene along our transect is one of an outbuilding system, going from open marine to terrestrial deposits, which is a classic sequence stratigraphic configuration.

- The lower part of the Maassluis Formation in the Noordwijk borehole lies below an unconformity and consists of open marine sediments as opposed to the coastal sediments of the upper part. Since it is the normal transition over a sequence boundary, there is reason to speculate about which sequences we are looking at here and what their age is. There is a large sedimentary wedge to the west of Noordwijk that is missing in the Noordwijk borehole.

- The glacial-interglacial cycles Meijer et al. (in press) refer to are likely to be better expressed in the coastal part of the formation, i.e. from ca. $2.55 \mathrm{Ma}$. This is also the part of the formation where micro-vertebrates will be found, not the (older) marine part. These cycles do not alter the overall sequence stratigraphic model, they add a climatic overprint of smaller sedimentary cycles.

Our study was intended to establish if Sr-isotope age dating was feasible in the Maassluis Formation. The lesson was that this needs to be undertaken on a more detailed level, with closer spaced boreholes, closer spaced samples and using the latest selection procedures for the shell material to be used. Diagenetic overprint can be expected.
We agree with Wesselingh et al. (this volume) that Sr age measurements should be accompanied by other chemical data, such as trace element abundance and oxygen isotope data, and with other stratigraphic data, such as biostratigraphy and magnetostratigraphy.

As to their conclusion that there is very hard molluscan and vertebrate evidence for a Tiglian-Praetiglian age for the Maasluis Formation, we must mention that this depends on the definition of the formation. We certainly believe this to be true for the coastal part in the Noordwijk borehole (above the unconformity), but suggest you keep an open mind about the lower part.

\section{References}

Jansen, H.S.M., Huizer, J., Dijkmans, J.W.A. \& Van Hinte, J.E., 2004. Strontium dating of marine shells from Pliocene and Pleistocene shallow marine deposits in The Netherlands. Netherlands Journal of Geosciences / Geologie en Mijnbouw 83: 1-48.

Jansen, H.S.M., Huizer, J., Dijkmans, J.W.A., Mesdag, C. \& Van Hinte, J.E., 2004. The geometry and stratigraphic position of the Maasluis Formation (western Netherlands and southeastern North Sea). Netherlands Journal of Geosciences / Geologie en Mijnbouw 83: 93-100.

Meijer, T., Cleveringa, P., Munsterman, D.K. \& Verreussel, R.M.C.H., 2005. The Early Pleistocene Praetiglian and Ludhamian pollen stages in the North Sea Basin and their relationship to the marine isotope record. Journal of Quaternary Science (in press). 